\title{
Geospatial analysis of births with congenital disorders, Paraná, 2008-2015: ecological study
}

\author{
Análise geoespacial dos nascimentos com anomalias congênitas, Paraná, 2008-2015: estudo ecológico \\ Análisis geoespacial de los nacimientos con anomalías congénitas, Paraná, 2008-2015: un estudio ecológico
}

\section{Márcia Helena de Souza Freire' \\ ORCID: 0000-0003-3941-3673 \\ Ana Paula de Morais Maia Barros' \\ ORCID: 0000-0003-2223-4513 \\ Luciano de Andrade' \\ ORCID: 0000-0003-2077-1518 \\ Oscar Kenji Nihei" \\ ORCID: 0000-0002-9156-7787 \\ Kátia Biagio Fontes"II \\ ORCID: 0000-0002-1928-482X}

'Universidade Federal do Paraná. Curitiba, Paraná, Brazil.

"Universidade Estadual do Oeste do Paraná.

Foz do Iguaçu, Paraná, Brazil.

"' Universidade Estadual de Maringá. Maringá, Paraná, Brazil.

How to cite this article:

Freire MHS, Barros APMM, Andrade L, Nihei OK, Fontes KB. Geospatial analysis of births with congenital disorders, Paraná, 2008-2015: ecological study. Rev Bras Enferm. 2020;73(3):e20180741. doi: http://dx.doi.org/10.1590/0034-7167-2018-0741

Corresponding author:

Ana Paula de Morais Maia Barros

E-mail: anapaula.barros1984@gmail.com

EDITOR IN CHIEF: Antonio José de Almeida Filho ASSOCIATE EDITOR: Elucir Gir

Submission: 09-23-2018

Approval: 05-22-2019

\begin{abstract}
Objective: analyze the pattern of spatial distribution of the prevalence rate of births with congenital disorders and its relationship with social, economic, health care and environmental indicators in Paraná, Brazil, from 2008 to 2015. Method: ecological study with variables extracted from secondary banks, related to the births of children of mothers residing in Paraná, in two quadrennial (2008-2011 and 2012-2015). The analysis of the rates was performed with univariate spatial (Moran) and multivariate approach (Ordinary Least Squares and Geographically Weighted Regression). Results: the occurrence of congenital disorders presented a significant association $(p<0.05)$ with: registration in primary care of pregnant women over 20 years of age; urbanization degree; consumption of pesticides; and balance of female formal employment. Conclusion/Final considerations: social, health care and environmental variables showed a non-stationary spatial pattern in the analyzed period and influenced positively and negatively the rates.

Descriptors: Congenital Disorders; Population Spatial Distribution; Epidemiologic Method; Spatial Regression; Newborn.
\end{abstract}

\section{RESUMO}

Objetivo: Analisar o padrão de distribuição espacial da taxa de prevalência dos nascimentos com anomalias congênitas e sua relação com indicadores sociais, econômicos, de atenção à saúde e ambientais no estado do Paraná, Brasil, de 2008 a 2015. Método: Estudo ecológico com variáveis extraídas de bancos secundários, relativas aos nascimentos de filhos de mães residentes no estado do Paraná, em dois quadriênios (2008-2011 e 2012-2015). A análise das taxas foi realizada com abordagem espacial univariada (Moran) e multivariada (Ordinary Least Squares e Geographically Weighted Regression). Resultados: A ocorrência de anomalias congênitas apresentou associação significativa $(p<0,05)$ com: cadastramento na atenção primária de gestantes maiores de 20 anos; grau de urbanização; consumo de agrotóxicos; e saldo de emprego formal feminino. Conclusão: As variáveis sociais, de atenção à saúde e ambientais demonstraram padrão espacial não estacionário no período analisado e influenciaram positiva e negativamente as taxas.

Descritores: Anormalidades Congênitas; Distribuição Espacial da População; Aplicações da Epidemiologia; Regressão Espacial; Recém-Nascido.

\section{RESUMEN}

Objetivo: Evaluar el patrón de distribución espacial de la tasa de prevalencia de los nacimientos con anomalías congénitas y su relación con los indicadores sociales, económicos, medioambientales, de atención a la salud en el estado de Paraná, Brasil, de 2008 a 2015. Método: Estudio ecológico con variables de bancos secundarios, relativas a los nacimientos de hijos de madres residentes en el estado de Paraná, en dos cuatrienios (2008-2011 y 2012-2015). Se hizo el análisis de las tasas desde el análisis espacial univariada (Moran) y multivariante (Ordinary Least Squares y Geographically Weighted Regression). Resultados: La presencia de anomalías congénitas presentó una asociación significativa $(p<0,05)$ con: el registro en la atención primaria de gestantes mayores de 20 años de edad; el grado de urbanización; el consumo de agrotóxicos; y el saldo de empleo formal femenino. Conclusión: Las variables sociales, medioambientales y de atención a la salud demostraron haber un patrón espacial no estacionario en el período analizado, además influenciaron positiva y negativamente las tasas. Descriptores: Anomalías Congénitas; Distribución Espacial de la Población; Usos de la Epidemiología; Regresión Espacial; Recién nacido. 


\section{INTRODUCTION}

According to the World Health Organization (WHO), the congenital disorder (CD) comprises any malformation found in the newborn, intrauterine or after birth, whether of a structural, functional or metabolic nature ${ }^{(1)}$. Internationally, CD affect $3 \%$ of live births $(\mathrm{LB})^{(2)}$ and become the leading cause of child deaths in developed countries such as the United States and Japan ${ }^{(3-4)}$.

From 1990 to 2015, Brazil presented a 70.7\% drop in the infant mortality rate (47.1 to 13.8 deaths/1000 LB). However, CD have moved from fifth to second place among the causes of death since $1999^{(5)}$. In Paraná, CD were the second leading cause of child deaths in the period from 2007 to $2016^{(6)}$. Thus, its prevalence became a significant public health problem despite the improvement in the general health indicators of the population ${ }^{(7)}$.

In recent years, international geospatial analysis studies identified spatial patterns of $C D$ in Israel ${ }^{(8)}$ and the association of $C D$ with low birth weight in the USA ${ }^{(9)}$. The spatial distribution of some specific types of $C D$, such as gastroschisis ${ }^{(10)}$ and neural tube defects, was also analyzed ${ }^{(11)}$. In Brazil, only one study was identified, in Mato Grosso, with the purpose of identifying the spatial pattern of $C D^{(12)}$. Thus, the analysis of the pattern of spatial distribution of the prevalence rate of births with CD in association with social, economic, health care and environmental indicators is an innovative approach in the Brazilian scenario.

\section{OBJECTIVE}

Analyze the pattern of spatial distribution of the prevalence rate of births with CD and its relationship with social, economic, health care and environmental indicators in Paraná, Brazil, from 2008 to 2015.

\section{METHOD}

\section{Ethical aspects}

This study complied with the standards of Resolution 466/2012 of the National Health Council $^{(13)}$, being reviewed and approved by the Comitê de Ética em Pesquisa (CEP - Research Ethics Committee) of the Universidade Federal do Paraná (UFPR) and the Secretaria Estadual de Saúde do Paraná (SESA - State Secretariat of Health of Paraná).

\section{Design, period and place of study}

This is a retrospective ecological study that used public databases to filter secondary data on births, mortality and primary care registration. The banks surveyed were: Sistema de Informações sobre Nascidos Vivos (SINASC - Live Birth Information System) $^{(14)}$ and Sistema de Informações sobre Mortalidade (SIM - Mortality Information System) ${ }^{(6)}$, relating to the period from 2008 to 2015; and Sistema de Informações de Atenção Básica (SIAB - Basic Care Information System) ${ }^{(15)}$, from 2012 to 2015 , all provided by DATASUS by the system Tabwin ${ }^{\circ}$. The data related to the economic variables were obtained from the database BDEweb ${ }^{\circ}$, of the Instituto Paranaense de Desenvolvimento Econômico e Social (IPARDES - Paraná Institute for Economic and Social Development)(16), research institution associated with the Secretaria de Estado do Planejamento e Coordenação Geral do Estado do Paraná (SEPL - State Secretary of Planning and General Coordination of Paraná). The base is supplied with data from the last census of the Brazilian Institute of Geography and Statistics (IBGE), of 2010. Finally, we used data available from Agência de Defesa Agropecuária do Paraná (ADAPAR - Agricultural Defense Agency of Paraná) ${ }^{(17)}$ from 2013 to 2015 . The agency establishes norms, standards, and procedures for measures to prevent and preserve the health of Paraná's agricultural production.

All data were collected between November 2017 and February 2018 and reviewed in a double-checking process. The period covered, which runs from 2008 to 2015, was divided into two quadrennial: from 2008 to 2011 ( $1^{\text {st }}$ qd) and from 2012 to 2015 ( $2^{\text {nd }} q d$ ).

The place studied was Paraná, located in the southern region of Brazil (latitude 22 $30^{\prime} 58^{\prime \prime}$ and $26^{\circ} 43^{\prime} 00^{\prime \prime}$, longitude $48^{\circ} 05^{\prime} 37^{\prime \prime}$ and $\left.54^{\circ} 37^{\prime} 08^{\prime \prime}\right)$. Paraná has 399 municipalities, $91.2 \%$ of which have less than 20,000 inhabitants ${ }^{(16)}$. The municipalities are distributed in 10 geographical mesoregions, in an area of 199,305 $\mathrm{km}^{2}$. In 2010, Paraná had 10,444,526 inhabitants. The fact that it has the fifth best Human Development Index of Brazil, with an HDI of 0.749 (Figure 1) ${ }^{(16)}$, contrasts with important regional economic differences: the north, west and metropolitan regions are more developed, and the central and southern regions less developed. These regional differences are important to understand the findings of this study.

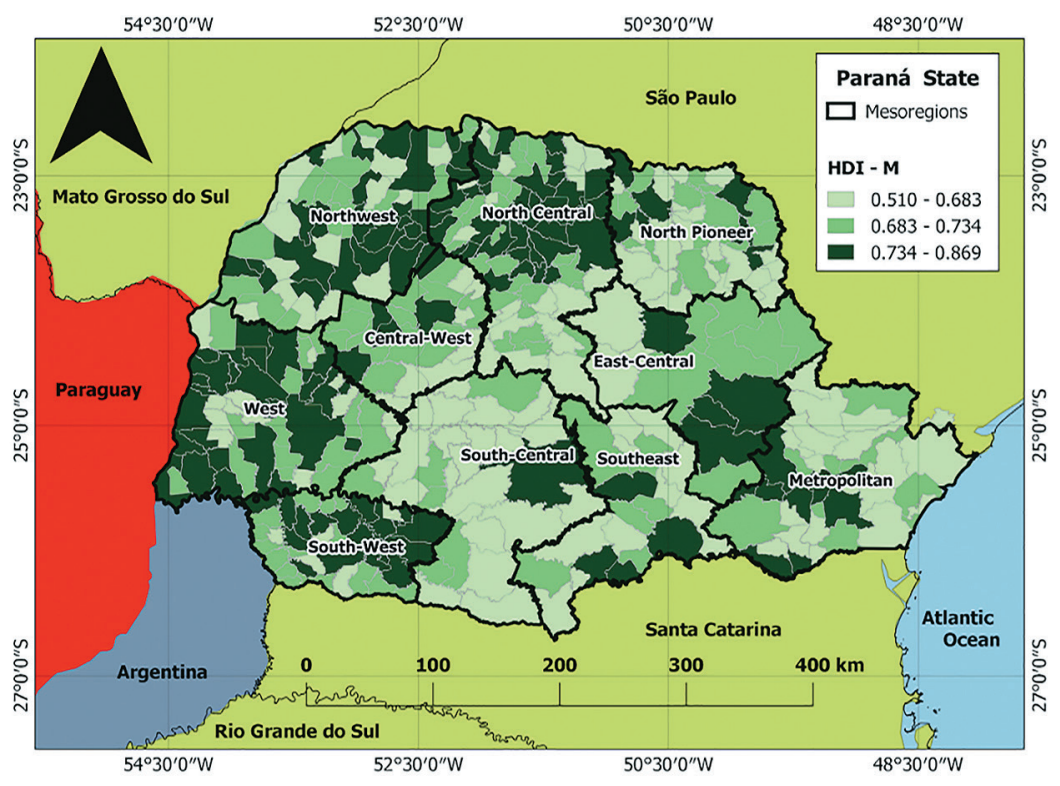

Source: IPARDES, 2010.

Figure 1 - Map of administrative regions and Human Development Index levels of municipalities in Paraná, Brazil, 2018 


\section{Population or sample; inclusion and exclusion criteria}

Data were included for all live births (LB) and fetal deaths/ stillbirths, in the period from 2008 to 2015, of mothers living in Paraná who had their live birth certificates (LBC) and death certificates (DC) completed and registered in SINASC and SIM.

\section{Study protocol}

The guidelines of Strengthening the Reporting of Observational Studies in Epidemiology (Strobe) were followed to organize the study from its methodological design ${ }^{(18)}$. We adopted the WHO guideline that recommends counting, in addition to live births with and without $C D$, stillbirths, or fetal deaths, with and without $C D$, multiplying the result by $10,000 \mathrm{LB}$, to calculate the prevalence rate of births with congenital disorders (PRBCD) in the 399 municipalities of the state ${ }^{(19)}$. These are the independent variables.

\section{Analysis of results and statistics}

In the exploratory analysis of spatial data, the empirical Bayesian estimator was used to minimize possible random fluctuations of the rates derived from municipalities with small populations ${ }^{(20-21)}$, since the estimator calculates a weighted rate considering regional variances ${ }^{(20-23)}$. The matrix of queen weights in the GeoDa software (v. 1.10.0.8), which considers all the neighborhoods, was used for this ${ }^{(21-23)}$.

Spatial autocorrelation was analyzed according to PRBCD and based on the Moran Global Index, which varies between -1 and +1. Values higher or lower than expected by the Moran Index (E (I) $=-1 /(n-1))$ indicate positive or negative autocorrelation, respectively. From this perspective, a positive spatial autocorrelation indicates that neighboring areas present similar values to those of the analyzed area, and a negative spatial autocorrelation indicates that neighboring areas present different values in relation to the analyzed area. A Global Moran Index close to zero indicates spatial independence.

The Moran Global Index can hide local patterns of spatial association, considering that values close to zero do not necessarily indicate no spatial correlation at the local level. Therefore, the analysis of local indicators of spatial association (Lisa) was performed in the GeoDa software, allowing the evaluation of rates relative to neighborhood, detecting the presence of significant spatial clusters according to PRBCD, visualized by choropleth maps and with data divided by quartiles ${ }^{(24-25)}$. With this analysis, the detected spatial clusters presented the following patterns: high-high (municipalities with high rates and neighbors with high rates); low-low (municipalities with low rates and neighbors with low rates); high-low (municipalities with high rates and neighbors with low rates); e low-high (municipalities with low rates and neighbors with high rates).

The global and local spatial autocorrelation coefficients were considered significant when $\mathrm{p}<0.05$. Both the Moran Global Index and the Lisa analysis focus on detecting spatial patterns and systematic variation of the phenomenon by location ${ }^{(26)}$, being used in this study for univariate analysis.

In relation to the multivariate spatial regression models, the independent PRBCD variable (representative only of the $2^{\text {nd }} \mathrm{qd}$ ) was analyzed for each municipality, due to the obtaining of the most recent secondary data (namely: availability of the last Census of 2010), and dependent, social, economic, environmental and health care variables, using the Ordinary Least Squares (OLS) and Geographically Weighted Regression (GWR) models.

The OLS method generates a linear regression model that seeks to explain the global relationship between the independent variable and the dependent variables ${ }^{(22,26)}$. The GWR method, in turn, has its coefficients estimated locally, from the spatial variability in each area. Thus, initially, the coefficients of each variable that were significant in the general model (OLS) were tested in the local model (GWR) $(21,27)$.

In order to reduce multicollinearity and favor the performance of the multivariate analysis model, an iterative sensitivity analysis was conducted. The model was chosen based on the Akaike (AIC) information criterion and the best adjusted $\mathrm{R}^{2}$, classic methods of selection of dependent variables in the multivariate regression model ${ }^{(25)}$. Finally, after analyzing several variables, only the predictors with the greatest potential to explain the births of babies with CD in the municipalities were included in the model, namely: pregnant women over 20 years old registered in primary care (we chose to work from this age, as it was the period of higher fertility of the woman, when more births occur) ${ }^{(28-29)}$; urbanization degree (percentage of residents in urban areas); formal female employment balance (admitted and dismissed); and consumption of pesticides (volume traded).

To evaluate the performance of OLS (classic) and GWR (spatial), these models were compared considering as parameters the adjusted $\mathrm{R}^{2}$, the AIC and the lowest variability of the resulting residues of each model ${ }^{(21,30)}$. The OLS model was processed in the GeoDa program, version 1.10.0.8 (Spatial Analysis Laboratory, University of Illinois at Urbana-Champaign, USA). The GWR model was implemented with the GWR program, version $4.0^{(26-}$ ${ }^{27,30)}$. The choropleth maps were generated in the QGIS software, version $2.14^{(31)}$

\section{RESULTS}

Comparing the quadrennial in study, $1^{\text {st }} q d$ and $2{ }^{\text {nd }} q d$, it was verified that the median of PRBCD was 78.3 and $78.8 / 10,000$ LB, respectively, and the maximum PRBCD increased from 145/10,000 LB $\left(1^{\text {st }} q d\right)$ to $182 / 10,000$ LB ( $\left.2^{\text {nd }} q d\right)$ (Figure 2$)$. From one period to another, the western, north-central and southwestern regions presented a higher number of municipalities with high rates. The opposite occurred in the northwest, midwest, east-central and north-pioneer regions (Figure 2).

In the global analysis of univariate Moran according to PRBCD, significant positive spatial autocorrelation was identified in the whole state, both for the $1^{\text {st }} q d(I=0.6133 ; p<0.0001)$ and for the $2^{\text {nd }} q d(l=0.7263 ; p<0.0001)$.

The Lisa analysis indicated the presence of six high-high type clusters, covering 65 municipalities with high PRBCD, located predominantly in the western, center-south, southeastern, northpioneer and metropolitan regions (Figure 3). In the $2{ }^{\text {nd }} \mathrm{qd}$, six high-high clusters were also identified, with 64 municipalities located predominantly in the western, center-south, southwestern, north-central and metropolitan regions (Figure 3 ). 

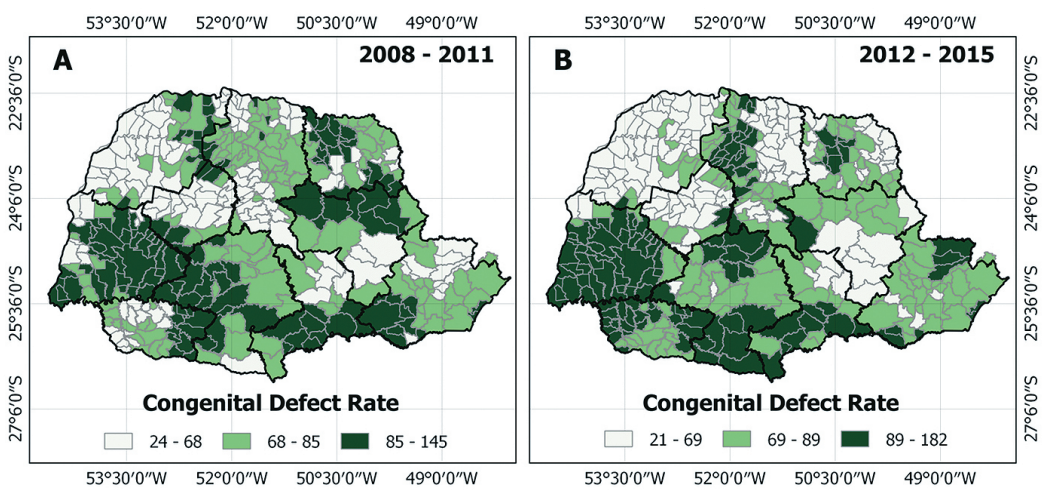

Figure 2 - Maps with birth prevalence rates with congenital disorders according to mesoregions, Paraná, Brazil, 2008 to 2011 ( $\left.1^{\text {st }} q d\right)$ and 2012 to 2015 ( $\left.2^{\text {nd }} q d\right)$
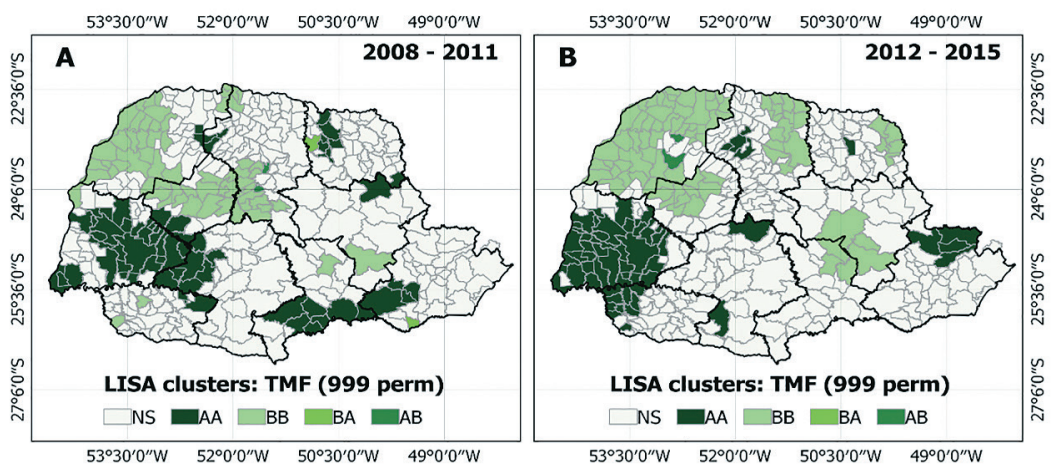

Figure 3 - Maps with the spatial distribution of the prevalence rate of births with CD (PRBCD and TMF) according to clusters, in Paraná, Brazil, 2008 to 2011 (1 $\left.1^{\text {st }} q d\right)$ and 2012 to 2015 ( $2^{\text {nd }} q d$ )

Table 1- Results of the analyses of the global regression model (OLS) and the local weighted regression model (GWR) in relation to dependent variables, in the municipalities of Paraná, Brazil, 2012-2015

\begin{tabular}{|c|c|c|c|c|c|c|}
\hline & \multicolumn{3}{|c|}{ OLS } & \multicolumn{3}{|c|}{ GWR } \\
\hline & $\begin{array}{l}\text { Estimated } \\
\text { Value }\end{array}$ & SE & T (Est/SE) & Minimum & Medium & Maximum \\
\hline Interception & 71.5317 & 5.7427 & 12.4561 & 34.9501 & 74.7625 & 114.2936 \\
\hline Pregnant women $>20^{1}$ & -0.0043 & 0.0039 & -1.1051 & -0.1237 & -0.0187 & 0.1399 \\
\hline UD & -0.1143 & 0.0487 & -2.3471 & -0.3734 & 0.0776 & 0.6808 \\
\hline Employment-fem. & 0.0016 & 0.0078 & 2.0979 & -0.0531 & 0.0134 & 0.0851 \\
\hline$P E$ & 0.0085 & 0.0033 & 2.5645 & -0.0465 & 0.0028 & 0.0420 \\
\hline $\mathrm{R}^{2}$ adjusted $^{2}$ & 0.0497 & & & 0.4521 & & \\
\hline AIC & 3592.8 & & & 3407.1 & & \\
\hline
\end{tabular}

Note: $T$ = test $T ; S E=$ standard error $;$ Est = estimate; $U D=$ urbanization degree; Fem = female; $P E=$ Pesticides; $A / C=$ Akaike's information criteria; ${ }^{1}$ Pregnant women over 20 years old registered in primary care; ${ }^{2}$ Coefficient of determination $\left(R^{2}\right)$ adjusted.

Six clusters of low-low type were identified in the $1^{\text {st }} q d$, framing 64 municipalities with low PRBCD, with predominance of municipalities in the northwest, north-central and midwest regions. In the $2^{\text {nd }} \mathrm{qd}$, four clusters of low-low type were identified, containing 85 municipalities located mostly in the northwest, midwest, north-central, north-pioneer, eastern-central and southeastern regions (Figure 3 ).

Two clusters of the high-low type and two of the low-high type with few municipalities were also detected in $1^{\text {st }} q d$. In $2^{\text {nd }} q d$, two clusters of the high-low type were detected, also with a very small number of municipalities (Figure 3).

Table 1 shows the results of the GWR spatial regression model (adjusted $R^{2}=0.4521$ ), of greater suitability compared to the OLS model (adjusted $R^{2}=0.0497$ ), for the analysis of the spatial relationship between the $2^{\text {nd }} q d$ PRBCD (2012 to 2015) and the dependent variations tested, highlighting those with greater predictive power of local variations of the PRBCD according to the GWR model: the number of pregnant women over 20 years old registered in primary care, urbanization degree, the use of pesticides and the balance of female formal employment.

In Figure 4A and 4B about the local spatial association between PRBCD and the variable "pregnant women $>20$ years old, registered in primary care", it was verified that the determination coefficients $\left(R^{2}\right)$ between the observed values and the values of the GWR model are heterogeneous in Paraná. The highest positive coefficients were observed in the cities of the midwest region, and the highest negative coefficients were observed in the northwestern and north-central regions (Figure 4A). And the "t-value", which indicates the level of adjustment of each independent variable in the GWR model, demonstrated that the parameter estimates were reliable. This analysis shows that the independent variable influences the PRBCD positively (dark green areas) in the metropolitan region and in some municipalities in the western, southeastern, and midwest regions; and negatively (light green areas) in municipalities in the northern part of the northwestern region and northwestern segment of the north-central region (Figure 4B).

The information generated in the analysis indicated that in the metropolitan region the registration of pregnant women $>20$ years of age is related to increased occurrence of CD. However, in the northwest and north-central regions, this variable proved to be protective, the PRBCD was reduced.

Regarding the association between PRBCD and the variable "urbanization degree" (UD) (Figure 4C and 4D), the positive determination coefficients were higher, as well as the positive $t$ values (>1.96) were found predominantly in cities in the northwest, midwest and north-central regions, with lower significance in the west and center-south regions (Figure 4C). This information indicates the directly proportional relationship between the UD and the PRBCD, which means that the higher UD, the higher the PRBCD. Negative coefficients and negative t values $(<-1.96)$ were located in a few cities in the western region and between the midwest and center-south regions, where the lowest UD is related to high PRBCD.

As shown in Figures 4E and 4F, small coefficients were found in the association between PRBCD and the variable "use of pesticides", which may indicate the influence of other dependent variables on local spatial variations. There was significance and positive t-values (>1.96), with emphasis on regions with high PRBCD and high consumption of agricultural pesticides, relating the municipalities of the western, northwestern and midwest regions (Figure 4F). 

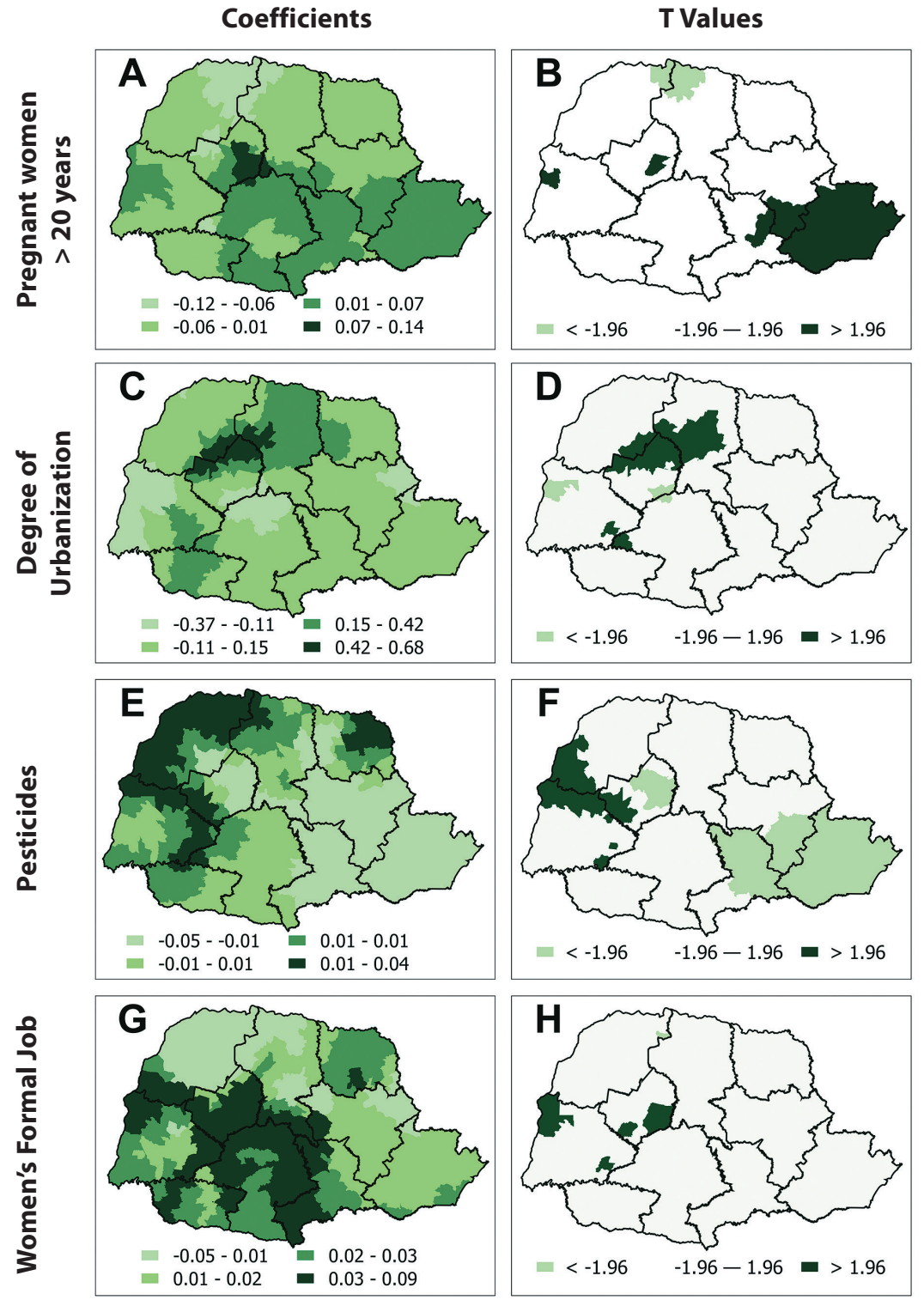

Note: $A$ and $B=$ "pregnant women $>20$ years old"; $C$ and $D=$ "urbanization degree"; $D$ e $F=$ "pesticide use"; GeH: "formal female employment".

Figure 4 - Maps with results of the GWR analysis and indication of the determination coefficients and $t$ values of the relationship between prevalence rate of births with congenital disorders (PRBCD) and variables, Paraná, Brazil, in the period from 2012 to 2015 ( $2^{\text {nd }} q d$ )

four clusters of the west and midwest regions, which indicates the presence in these areas of high rates of female employment related to high PRBCD (Figure 4H).

\section{DISCUSSION}

In Paraná, considering a period of 8 years, the maximum PRBCD were 145/10,000 LB and $182 / 10,000$ LB respectively, and the medians ranged from 78.3 to $78.8 / 10,000 \mathrm{LB}$.

The maximum values are close to those of the municipality of São Paulo (Brazil), which was $160 / 10,000$ LB $^{(32)}$, but lower than those of the United States (300/10,000 LB in 2006) (33), Chile (390/10,000 LB in 2010) $)^{(34)}$ and China $(780 / 10,000 \text { LB in 2012) })^{(35)}$. In this reading, it is important to think about the differences in the calculation of rates, since in none of the studies were accounted for fetal deaths, as indicated by the WHO and followed in this research.

Positive spatial autocorrelation according to PRBCD was significant in the municipalities and confirmed by Lisa's analysis, which detected a predominance of high-high clusters in both periods, in the western and metropolitan regions, as well as low-low clusters also predominated in both periods, in the northwest, north-central and central-western regions. This scenario points to the heterogeneity of PRBCD in Paraná, what can be explained by several factors, such as exposure to teratogenic agents, maternal age, exposure to pesticides, access and adherence to prenatal care and reference hospitals, among others.

Also regarding the heterogeneity of prevalence rates found in Paraná, the possible underreporting is noteworthy, since the median rates in some municipalities present much lower results than those of previous studies. Authors point out that, despite the development and improvement of SINASC over the years and the inclusion of a block on CD

The coefficients of negative determination, among the municipalities with values of $t$ lower than -1.96 , in which there was low PRBCD regarding the use of pesticides, include all of the metropolitan region, much of the southeast and part of the midwest and eastern-central regions. In conclusion, the predictive variable "pesticides consumption" is associated with the high PRBCD in the western, northwestern and central-western regions of the state (Figure $4 \mathrm{~F}$ ).

In the association between PRBCD and the variable "formal female employment balance", the highest relative positive determination coefficients were verified, especially in the municipalities of the western, central-western, south-western, south-central, southeastern and in part of the northwestern region (Figure $4 G)$. In addition, the positive t values (>1.96) were evidenced in notification since 1999, there may still be failures characterized by the non-identification of some types of cardiac CD, such as late diagnosis or less severe. These are factors for this possible underreporting: lack of a team prepared to make the diagnosis or even a neonatologist in the delivery room and professionals trained to fill the $L B C$; resistance of parents regarding the registration of the event in the child's document, especially in private institutions; and stage of development of fetal medicine, since early diagnosis of CD can motivate illegal abortion ${ }^{(28,36)}$. Other factors related to differences in PRBCD values will be discussed later using spatial regression.

In the GWR multivariate spatial regression model, one of the predictor variables that was associated with CD birth was"pregnant women $>20$ years of age registered in primary care", being 
this the period (from 20 to 34 years of age) of higher fertility and higher occurrence of births according to a national survey in $2017^{(37)}$. In Brazil, the monitoring and quality of prenatal care and childbirth care is currently recognized as an important strategy to prevent and reduce the risk of mortality, both for pregnant women and children ${ }^{(37-38)}$. Thus, the registration of pregnant women in a timely manner, with guaranteed access to the health system and adequate monitoring, including the performance of protocol exams for the detection of diseases and risk stratification, with subsequent referral to specific services is pointed out as essential. These conditions can ensure adequate prenatal and childbirth facilities ${ }^{(37,39)}$.

In the model analyzed, high registration was associated with high PRBCD, which may be due to the demographic-population characteristics of the regions. As an example, it is pointed out the metropolitan region, the most populated in Paraná, presenting in almost all its territory positive determination coefficients. The fact may also be associated with better and faster diagnoses, in addition to more effective recording in SINASC of the findings arising from the diagnosis of $C D$, which is an explanation associated with the heterogeneity of the PRBC in the state.

Another predictor variable that was associated with birth with $C D$, according to the multivariate spatial regression model GWR, was the "urbanization degree" (UD). It is noteworthy that the UD of Paraná is $85.3 \%$, considered high, however $91.2 \%$ of its municipalities have less than 20,000 inhabitants ${ }^{(16)}$. In this aspect, a study conducted with 800,000 Danish children, born in the period from 1993 to 2005, associated the autistic spectrum disorder to the UD, highlighting the greater effectiveness and availability of diagnosis in urbanized areas ${ }^{(40)}$.

Considering the positive determination coefficients for UD, we associated our findings with evidence that malformed newborns living in less populated areas or with lower UD are at risk of having a late diagnosis compared to newborns living in more densely populated areas. In these areas of lower UD, there may still be verbal diagnosis but failures in registration, as pointed by other studies that also used SINASC data ${ }^{(28,36)}$.

Considering its diversified territorial dimension, Brazil is still in industrial growth despite the economic crisis. It is expected, therefore, that regions will suffer from increasing exposure to risks to embryonic-fetal health arising from contamination inherent to industrial activities ${ }^{(41)}$.

Another predictor variable that was associated with PRBCD in the GWR model was "pesticide consumption," corroborating data related to economic activity in Paraná. Agriculture and ranching stand out in the economy of Paraná as the second sector of occupation of the population according to IPARDES ${ }^{(42)}$.

In a Brazilian study, Paraná ranked second among the states that most use pesticides, consuming 135 million liters in 2015, losing only to Mato Grosso ${ }^{(43)}$. The high consumption of pesticides may be associated with an increase in CD cases. In this perspective, in the future, $C D$ may become the main cause of child mortality in Paraná, as occurs in some developed countries.

A survey conducted in Mato Grosso identified four times more $\mathrm{CD}$ among newborns of mothers working in agriculture compared to mothers working in other activities ${ }^{(44)}$. A case-control study, developed in the Brazilian northeast, pointed out that the direct or indirect exposure of women to substances present in pesticides increases the risk of $\mathrm{CD}^{(45)}$.

Another predictor variable associated with PRBCD in the GWR model was "formal female employment". Some epidemiological studies about this relationship have been developed in order to evaluate the association between maternal occupational exposure and adverse reproductive outcomes, including increased occurrence of $\mathrm{CD}^{(46-47)}$. In a study conducted in New York City with female workers exposed to metals, chlorinated hydrocarbons and other hydrocarbons during the period of organogenesis, at least five cases of newborns with cardiac disorders were observed ${ }^{(48)}$.

It is also emphasized that the mother who works formally (a scenario widely current in Brazil), while providing better living conditions for her child, may be more exposed to various teratogenic agents in the occupational environment. Despite the lack of research that elucidates this relationship, considering social, economic and cultural differences, there is a research of the National Birth Defects Prevention Study, conducted in the USA in the period from 1997 to 2011, associating occupational exposure to aromatic hydrocarbons with higher risk of anencephaly and spina bifida ${ }^{(49)}$.

\section{Study limitations}

It is necessary to point out that the main limitation of this research is the inexistence of worldwide standardization for calculation of PRBCD. In this study, the calculation recommended by theWHO was adopted, since the number of fetal deaths proven to have occurred due to $C D$ is considered relevant. Thus, the comparison between rates should be made with caution. Another limitation is the fact that the research uses secondary data; even if they belong to good quality databases, some information may be underreported, leading to biases. And, finally, it is worth mentioning the unavailability of more recent data for some indicators, since the information used is from the 2010 Census.

\section{Contributions to the area of nursing, health and public policies}

Knowledge about risk factors for CD can support strategic planning with political-administrative management tools that impact on the services of the maternal and child care network, enabling the assessment of gaps that have persisted and determining child morbidity and mortality. From this point of view, it is important to create a reliable monitoring and analysis service of the occurrence and outcome of CD in the child population, both in Paraná and in other Brazilian states, under recommendation and federal supervision.

Faced with this scenario, the nurse stands out, a professional who has a large field of action in the area of maternal and child health, acting in management and in all levels of complexity. Thus, it is necessary to improve the training and qualification of these professionals to act in the prevention, treatment and rehabilitation of children with $C D$, who suffer from numerous comorbidities that may affect their lives for many years.

\section{FINAL CONSIDERATIONS}

PRBCD has increased, presenting an unequal spatial distribution in the different regions of Paraná. Social, health care, and environmental 
indicators also showed a non-stationary spatial pattern in the analyzed period. The predictor or dependent variables ("number of pregnant women $>20$ years of age registered in primary care", "urbanization degree", "use of pesticides" and "formal female employment") were significant to explain the spatial differences of PRBCD in Paraná. The GWR approach was relevant for allowing the identification of both positive and negative local spatial influences on prevalence rates, indicating the complexity of the state under study.

This research partially reveals the public health situation related to births with congenital anomalies, seeking to raise the development of an extensive research considering the variables analyzed as predictors.

\section{REFERENCES}

1. World Health Organization (WHO). Congenital anomalies [Internet]. Geneva: World Health Organization; 2016 [cited 2019 Apr 29 ]. Available from: https://www.who.int/news-room/fact-sheets/detail/congenital-anomalies

2. Moore KL, Persaud TVN. Anomalias congênitas ou defeitos congênitos humanos. In: Moore KL, Persaud TVN. Embriologia clínica. 8th ed. Rio de Janeiro: Guanabara Koogan; 2006. p. 161-93.

3. Centers for Disease Control and Prevention. Infant mortality statistics from 2013 period linked birth infant death data set [Internet]. Atlanta: Centers for Disease Control and Prevention; 2015 [cited 2018 Mar 19]. Available from: https://www.cdc.gov/nchs/data/nvsr/nvsr64/nvsr64_09.pdf

4. Hanaoka T, Tamura N, Ito K. Prevalence and risk of birth defects observed in a prospective cohort study: the hokkaido study on environment and children's health. J Epidemiol. 2018;28(3):125-32. doi: 10.2188/jea.JE20160108

5. Instituto Brasileiro de Geografia e Estatística (IBGE). População: taxas de mortalidade infantil [Internet]. 2016 [cited 2016 Aug 24 ]. Available from: http://brasilemsintese.ibge.gov.br/populacao/taxas-de-mortalidade-infantil.html

6. Ministério da Saúde (BR). Datasus. Óbitos fetais: Paraná[Internet]. Brasília, DF: Ministério da Saúde; 2019 [cited 2019 Apr 29]. Available from: http://tabnet.datasus.gov.br/cgi/deftohtm.exe?sim/cnv/fet10pr.def

7. Mendes CQS, Avena MJ, Mandetta MA, Magda M, Gomes F. Prevalência de nascidos vivos com anomalias congênitas no município de São Paulo. Rev Soc Bras Enferm Ped [Internet]. 2015[cited 2019 Apr 29];15(1):7-12. Available from: https://sobep.org.br/revista/component/zine/ article/201-prevalencia-de-nascidos-vivos-com-anomalias-congenitas-no-municipio-de-sao-paulo.html

8. Agay-Shay K, Amitai Y, Peretz C, Linn SA, Friger M, Peled A. Exploratory Spatial Data Analysis of Congenital Malformations (CM) in Israel, 2000-2006. J Geo-Inf. 2013;(2):237-55. doi: 10.3390/ijgi2010237

9. Rible R, Aquilar E, Bader JL. Exploration of spatial patterns of congenital anomalies in Los Angeles County using the vital statistics birth master file. Environ Monit Assess. 2018;190(4):184. doi: 10.1007/s10661-018-6539-0.

10. Yazdy MM, Werlwer MM, Anderka M, Langlois PH, Vieira VM. Spatial analysis of gastroschisis in Massachusetts and Texas. Ann Epidemiol. 2015(25)1:7-14.

11. Liao Y, Zhang Y, He L, Wang J, Liu X, Xu B. Temporal and Spatial Analysis of Neural Tube Defects and Detection of Geographical Factors in Shanxi Province, China. PLoS One [Internet]. 2016 [cited 2018 Mar 27]; 11(4):e0150332. Available from: https://www.ncbi.nlm.nih.gov/pmc/ articles/PMC4839670/

12. Morales MOCC. Georreferenciamento das anomalias congênitas no estado de Mato Grosso [dissertation]. Cuiabá: Universidade de Cuiabá; 2013.

13. Ministério da Saúde (BR). Conselho Nacional de Saúde. Resolução no 466/2012. Diário Oficial da União [Internet]. 2012 Dez 13 [cited 2019 Apr 26]. Available from: http://bvsms.saude.gov.br/bvs/saudelegis/cns/2013/res0466_12_12_2012.html

14. Departamento de Informação e Informática do SUS (Datasus). Nascidos Vivos: Brasil [Internet]. Brasília, DF: Ministério da Saúde. c2019 [cited 2017 May 8]. Available from: http://tabnet.datasus.gov.br/cgi/tabcgi.exe?sinasc/cnv/nvuf.def

15. Ministério da Saúde (BR). Sistema de Informação da Atenção Básica (Siab)[Internet]. Brasília, DF: Ministério da Saúde; 2019 [cited 2019 Apr 29]. Available from: http://www2.datasus.gov.br/SIAB/index.php

16. Instituto Paranaense de Desenvolvimento Econômico e Social. Curitiba: Instituto Paranaense de Desenvolvimento Econômico e Social. Anuário Estatístico do Estado do Paraná [Internet]. 2016 [cited 2018 Mar 27]. Available from: http://www.ipardes.pr.gov.br/anuario_2016/index.html

17. Agência de Defesa Agropecuária do Paraná. Agrotóxicos no Paraná [Internet]. 2019 [cited 2018 Mar 27]. Available from: http://www.adapar. pr.gov.br/modules/conteudo/conteudo.php?conteudo=389.

18. Malta M, Cardoso LO, Bastos FI, Magnanini MMF, Silva CMFP. STROBE initiative: guidelines on reporting observational studies. Rev Saúde Públ. 2010;44(3):559-65. doi: 10.1590/S0034-89102010000300021

19. World Health Organization WHO). Birth defects surveillance: a manual for programme managers [Internet]. Geneva: World Health Organization; 2014 [cited 2018 Jan 20]. Available from: http://apps.who.int/iris/bitstream/handle/10665/110223/9789241548724_eng.pdf?sequence=1.

20. Sousa MH, Bento SF, Osis MJ, Ribeiro MP, Faúndes A. Filling out the compulsory notification in health services that care for women who suffer from sexual violence. Rev Bras Epidemiol[Internet]. 2015[cited 2018 Jan 20];18:94-107. Available from: http://www.scielo.br/pdf/ rbepid/v18n1/en_1415-790X-rbepid-18-01-00094.pdf

21. Fontes KB, Jacinto Alarcão AC, Nihei OK, Pelloso SM, Andrade L, Barros Carvalho MD. Regional disparities in the intimate partner sexual violence rate against women in Paraná State, Brazil, 2009-2014: an ecological study. BMJ Open [Internet]. 2018 [cited 2018 Mar 10];8(2):e018437. Available from: http://www.ncbi.nlm.nih.gov/pubmed/29463587 
22. Anselin L, Syabri I, Kho Y. GeoDa: an introduction to spatial data analysis. Geogr Anal. 2006;38(1):5-22. doi: 10.1111/j.0016-7363.2005.00671.x

23. Santos $\mathrm{AE}$, Rodrigues AL, Lopes DL. Estimadores bayesianos empíricos para análise espacial das taxas de mortalidade [Internet]. In: VII Simpósio Brasileiro de Geoinformação. 2005; Nov 20-23; Campos do Jordão, Brazil. São José dos Campos: Inpe; 2005 [cited 2018 May 20]. Available from: http://mtc-m16c.sid.inpe.br/col/dpi.inpe.br/geoinfo@80/2006/07.11.13.29/doc/P63.pdf

24. Anselin L. Interactive techniques and exploratory spatial analysis. In: Longley PA, Goodchild MF, Maguire DJ, Wind DW, editors. Geographical information systems: principles, techniques, management and applications. New York: Wiley; 1998. p. 253-265.

25. Andrade L. Análise da distribuição espacial dos homicídios juvenis em um município brasileiro de tríplice fronteira [dissertation]. Maringá: Universidade Estadual de Maringá; 2009 [cited 2018 Mar 10]. Available from: http://nou-rau.uem.br/nou-rau/document/?code=vtls000177746

26. Anselin L. Local Indicators of Spatial Association - LISA. Geogr Anal. 1995;27(2):93-115.

27. Oliveira S, Pereira JMC, San-Miguel-Ayanz J, Lourenço L. Exploring the spatial patterns of fire density in Southern Europe using Geographically Weighted Regression. Appl Geogr. 2014;51:143-57. doi: 10.1016/j.apgeog.2014.04.002

28. Laurenti R, Siqueira AAF, Jorge MHPM, Gotlieb SLD, Pimentel EC. The importance of congenital malformations at birth. J Hum Growth Develop. 2014;24(3):328-338. doi: 10.7322/jhdg.88972

29. Csermely G, Urbán R, Czeizel AE, Veszprémi B. Sex ratio of congenital abnormalities in the function of maternal age: a population-based study. Congenit Anom Kyoto. 2015;55(2):85-91. doi: 10.1111/cga.12093

30. Ndiath MM, Cisse B, Ndiaye JL, Gomis JF, Bathiery O, Dia AT, et al. Application of geographically- weighted regression analysis to assess risk factors for malaria hotspots in Keur Soce health and demographic surveillance site. Malar J. 2015;14:463. doi: 10.1186/s12936-015-0976-9

31. QGIS Development Team. QGIS [Internet]. 2019 [cited 2017 Oct 23]. Available from: http://qgis.osgeo.org

32. Cosme WH, Lima LS, Barbosa LG. Prevalence of congenital anomalies and their associated factors in newborns in the city of São Paulo from 2010 to 2014. Rev Paul Pediatr. 2017;35(1):33-8. doi: 10.1590/1984-0462/;2017;35;1;00002

33. Centers for Disease Control and Prevention. Key findings: updated national birth prevalence estimates for selected birth defects in the United States, 2004-2006 [Internet]. Atlanta: Centers for Disease Control and Prevention; 2018 [cited 2019 Apr 26]. Available from: https:// www.cdc.gov/ncbddd/birthdefects/features/birthdefects-keyfindings.html

34. Nazer HJ, Cifuentes Ovalle L. Prevalencia al nacimiento de malformaciones congenitas en las maternidades chilenas participantes en el ECLAMC en el período 2001-2010. Rev Med Chile. 2014;142(9):1150-6. doi: 10.4067/S0034-98872014000900009

35. Yu M, Ping Z, Zhang S, He Y, Dong R, Guo X. The survey of birth defects rate based on birth registration system. Chin Med J. 2015;128(1):7-14. doi: 10.4103/0366-6999.147785

36. Pinto CO, Nascimento LFC. Estudo da prevalência de defeitos congênitos no Vale do Paraíba Paulista. Rev Paulis Pediatr. 2007;25(3):233-9. doi: 10.1590/S0103-05822007000300007

37. Ministério da Saúde (BR). Saúde Brasil 2015/2016: uma análise da situação de saúde e da epidemia pelo vírus Zika e por outras doenças transmitidas pelo Aedes aegypti. Brasília, DF: Ministério da Saúde; 2017 [cited 2018 Mar 20]. Available from: http://portalarquivos.saude.gov. br/images/pdf/2017/maio/12/2017-0135-vers-eletronica-final.pdf

38. Figueiredo PP, Wilson DLF, Lunardi VL, et al. Infant mortality and prenatal care: contributions of the clinic in the light of Canguilhem and Foucault. Rev Latino-Am Enfermagem. 2012;20(1):10. doi: 10.1590/S0104-11692012000100026

39. Secretaria de Estado da Saúde do Paraná. Linha guia: Rede Mãe Paranaense [Internet]. 2012[cited 2018 Mar 20]. Available from: http://www. saude.pr.gov.br/arquivos/File/ACS/linha_guia_versao_final.pdf

40. Lauritsen MB, Astrup A, Pedersen CB, Obel CB, Schendel DE, Schieve L, et al. Urbanicity and autism spectrum disorders. J Autism Dev Disord. 2014;44(2):394-404. doi: 10.1007/s10803-013-1875-y

41. Schüler-Faccini L, Leite JCL, Sanseverino MTV, Peres RM. Avaliação de teratógenos na população brasileira. Ciênc Saúde Coletiva. 2002;7(1):65-71. doi: 10.1590/S1413-81232002000100006

42. Instituto Paranaense de Desenvolvimento Econômico e Social. População ocupada, segundo principais setores de atividade econômica e os municípios do Paraná - 2010[Internet]. 2018 [cited 2018 May 20]. Available from: http://www.ipardes.pr.gov.br/anuario_2016/4economia/ tab4_1_2.htm

43. Pignatti WA, Lima FANS, Lara SS, Correa MLM, Barbosa JR, Leão LHC, et al. Distribuição espacial do uso de agrotóxicos no Brasil: uma ferramenta para a vigilância em saúde. Ciênc Saúde Coletiva. 2017; 22(10):3281-93. doi: 10.1590/1413-812320172210.177422017

44. Oliveira NP, Moi GP, Atanaka-Santos M, Silva AMC, Pignatti WA. Malformações congênitas em municípios de grande utilização de agrotóxicos em Mato Grosso, Brasil. Ciênc Saúde Coletiva. 2014;19(10):4123-30. doi: 10.1590/1413-812320141910.08512014

45. Silva SRG, Martins JL, Seixas S, Silva DCG, Lemos SPP, Lemos PVB. Defeitos congênitos e exposição a agrotóxicos no Vale do São Francisco. Rev Bras Ginecol Obstet. 2011;33(1):20-6. doi: 10.1590/S0100-72032011000100003

46. Brender JD, Felkner M, Suarez L, Canfield MA, Henry JP. Maternal pesticide exposure and neural tube defects in Mexican Americans. Ann Epidemiol. 2010;20:16-22. doi: 10.1016/j.annepidem.2009.09.011

47. Lacasaña M, Vázquez-Grameix H, Borja-Aburto VH, Blanco-Muñoz J, Romieu I, Aguilar-Garduño C, et al. Maternal and paternal occupational exposure to agricultural work and the risk of anencephaly. Occup Environ Med. 2006;63(10):649-56. doi: 10.1136/oem.2005.023333 
48. Silver SR, Pinkerton LE, Rocheleau CM, Deddens JA, Michalski AM, Van Zutphen AR. Birth defects in infants born to employees of a microelectronics and business machine manufacturing facility. R. A Clin Mol Teratol. 2016;106(8):696-707. doi: 10.1002/bdra.23520

49. Santiago-Colón A, Rocheleau C, Christianson A, Lawson C, Langlois P, Lupo P, et al. Maternal occupational exposures to polycyclic aromatic hydrocarbons and risk of neural tube defects in the national birth defects prevention study. Ann Epidemiol. 2018;28(9):665-6. doi: 10.1016/j. annepidem.2018.06.018 